\title{
Phenotypic characterization of açai palm germplasm from the Marajó's archipelago and Baixo Tocantins territories
}

\author{
Caracterização fenotípica de germoplasma de açaizeiro nos \\ territórios do Arquipélago do Marajó e do Baixo Tocantins
}

\author{
João Thiago Rodrigues de Sousa ${ }^{1 *}$; Milene Moara Reis Costa ${ }^{2}$; \\ Aline dos Santos Pereira ${ }^{2}$; Milton Guilherme da Costa Mota ${ }^{3}$
}

\begin{abstract}
The açai palm (Euterpe oleracea Mart.), a native of the Amazon region, is a food of great importance. Recently, due to the discovery of its nutraceutical properties, the rational production in upland areas has been encouraged. However, to support the rational implementation of its cultivation for fruit production, which is a sort of domestication process, it is necessary to identify its germplasm. The aim of this study was to evaluate and quantify the genetic diversity based on phenotypic characters among açai palm mother plants derived from 11 areas of the Amazonian estuary. Twenty-nine phenotypic descriptors were used: (i) 9 from the plant, (ii) 7 related to the fruit, and (iii) 13 of agronomic nature. Principal component analysis was used to assess the phenotypic variability from standardized data obtained from selected açai palm mother plants. In the selection of the descriptors, the methods of direct selection and selection with re-analysis were used. The disposal efficiency was estimated by comparing dissimilarity groups formed by 11 origins of the açai palms based on 29 original characters and 23 selected characters. The groups were formed using the average standardized Euclidean distance and Tocher's optimization method. All the analyses were performed using the GENES program. The selection of $79.31 \%$ of the descriptors used was significant and was considered sufficient for the evaluation of the açai palm germplasm for fruit production. The selected descriptors were shown to be capable of quantifying the phenotypic diversity of mother plants of this species, consistently grouping them using the optimization method. The cluster method showed small differences in the number and composition of the groups due to variability among the selected mother plants.
\end{abstract}

Key words: Descriptors. Diversity. Euterpe oleracea. Germplasm. Plant breeding.

\section{Resumo}

O açaizeiro (Euterpe oleracea Mart.) é uma palmeira nativa da região amazônica, de grande importância alimentar e, recentemente, devido à descoberta de suas propriedades nutracêuticas, está estimulando a produção racional em áreas de terra-firme. Para viabilizar essa expansão é necessário o conhecimento do seu germoplasma a fim dar suporte à implantação racional do cultivo para a produção frutos, pois trata-se de uma espécie em processo de domesticação. O objetivo deste trabalho foi avaliar e quantificar a diversidade genética entre matrizes de açaizeiro oriundas de 11 procedências do estuário amazônico, territórios do Arquipélago do Marajó e do Baixo Tocantins, baseada em caracteres fenotípicos. Foram empregados 29 descritores fenotípicos subdivididos em (i) nove relativos à planta, (ii) sete relativos ao fruto e (iii) 13 agronômicos. Foi utilizada a análise de componentes principais para avaliação da

${ }^{1}$ Prof. Dr., Universidade Federal do Oeste do Pará, UFOPA, Santarém, PA, Brasil. E-mail: thiagronomo@gmail.com

2 Discentes, Universidade Federal Rural da Amazônia, UFRA, Belém, PA, Brasil. E-mail: milene.moara@gmail.com; alinep233@ gmail.com

3 Prof. Dr., UFRA, Belém, PA, Brasil. E-mail: miltongmota@gmail.com

* Author for correspondence 
variabilidade fenotípica a partir dos dados padronizados obtidos das matrizes selecionadas. Na seleção de descritores foram empregados os métodos de seleção direta e de seleção com reanálise. A eficiência do descarte foi atestada pela comparação de grupos de dissimilaridades formados pelas 11 procedências de açaizeiros, baseados nos 29 caracteres originais e nos 23 caracteres selecionados. Os grupos foram formados utilizando a distância euclidiana média padronizada e o método de otimização de Tocher. Todas as análises foram realizadas no programa GENES. A seleção de 79,31\% dos descritores utilizados, foi significativa e deve auxiliar na avaliação de germoplasma de açaizeiro para a produção de frutos. Os descritores selecionados mostram-se capazes de quantificar a diversidade fenotípica de matrizes desta espécie, agrupando-as com consistência pelo método de otimização. O método de agrupamento mostrou diferenças no número e na composição dos grupos, mesmo evidenciando baixa dissimilaridade houve presença de variabilidade entre as matrizes selecionadas.

Palavras-chave: Euterpe oleracea. Germoplasma. Descritores. Diversidade. Melhoramento vegetal.

\section{Introduction}

The açai palm (Euterpe oleracea Mart.) is a native palm tree of the Amazon region, and is very common in the meadows of the estuary. Its inestimable socio-economic importance in the States of Pará and Amapá is due to its fruit being one of the main food sources of riverside and urban populations of the region (YOKOMIZO et al., 2012).

In the States, the production of açai results from extractivism, with extractivists using different levels of management with areas of rational cultivation following the recommendations of the production system. Although extractivism accounts for $13.1 \%$ of total production, in cultivated areas this reached more than 700 thousand tons over a harvested area of approximately 78 thousand hectares in 2010, which represents $86.9 \%$ of the total production (NOGUEIRA et al., 2013). In upland areas, the advance in açai production is driven by a market that needs improved cultivars adaptable to new growth conditions. Thus, the production systems require the propagation of genetic material of proven quality. Several studies focused on the genetic structure of populations, including genetic and phenotypic diversity, and on the definition of morphoagronomic descriptors. These allowed the selection process to occur more efficiently, enabling support of açai breeding programs and meeting production demands (FARIAS NETO et al., 2007, 2008; GALATE et al., 2014; OLIVEIRA et al., 2006, 2007, 2009, 2010; YOKOMIZO et al., 2010, 2012).
As a rule, the observation and assessment of a large number of characteristics is essential for the process of germplasm characterization when the number of accessions is huge. However, this tends to be redundant because characteristics are always associated with each other. Thus, the definition of a minimal set of descriptors reduces the need of collecting data without lowering the accuracy of the results (GALATE et al., 2012; OLIVEIRA et al., 2006; OLIVEIRA et al., 2010).

Many disposal procedures have been used with the aim of discarding characters providing low information, such as those used by Cury (2003) in Manihot esculenta Crantz, Oliveira et al. (2006), Galate et al. (2012) in Euterpe oleracea Mart., and Redig (2013) in Maximiliana maripa (Aublet) Drude. Multivariate analysis techniques such as principal component analysis (PCA), which analyzes multidimensional data by focusing most of the total variation in the first components, have been used to evaluate morphoagronomic characters. The efficiency of PCA was tested by comparing the groups formed by all the descriptors and those selected using the Tocher optimization method (GALATE et al., 2012; OLIVEIRA et al., 2006).

While conducting inter-population genetic breeding to obtain the expression of specific abilities or crossbreeding populations to achieve heterosis, it is essential to consider genetic divergence (FALCONER; MACKAY, 1996; HALLAUER; MIRANDA FILHO, 1981). Grouping analysis methods, which rely on morphological and 
agronomic characters in perennial plants, are frequently used to assess and interpret genetic divergence. When quantitative variables are used, the Euclidean distance is suggested as a measure of similarity, especially when the inserted germplasm does not meet the randomization and local control requirements commonly applied to experimental designs (CRUZ et al., 2004; OLIVEIRA et al., 2007).

Genetic diversity has been quantified in the germplasm of some Amazonian species such as cupuaçu, Theobroma grandiflorum (Willd. ex. Spreng.) Schum. (ARAUJO et al., 2002) and guarana, Paullinia cupana Kunth. (NASCIMENTO FILHO et al., 2001); in palm trees like pejibaye, Bactris gasipaes Kunth. (MARTEL et al., 2003), dende, Elaeis guineensis Jacq. (SANTOS et al., 2010), guarirobeira, Syagrus oleracea Mart. (PINTO et al., 2010), babassu, Orbignya phalerata Mart. (SANTOS, 2011), inajá, Maximiliana maripa (Aublet) Drude (REDIG, 2013) and açai, Euterpe oleracea Mart. (GALATE et al., 2012; OLIVEIRA et al., 2007). Thus, this study aimed at evaluating and quantifying the genetic diversity of açai palm mother plants from 11 collection sites in the Amazonian estuary. This was based on phenotypic characteristics, which were used to quantify the phenotypic variability, to select descriptors, to establish groups of mother plants with divergent phenotypic characteristics, and to indicate groups of plants with superior agronomic characteristics.

\section{Material and Methods}

From 2011 to 2014, in the period of açai fructification (i.e., July-December), 11 plants from different areas of the meadows of the Amazonian estuary were evaluated. Precisely, 148 samples were assessed (Table 1).

PCA was used to evaluate the phenotypic variability of the data obtained from the selected acai palm mother plants. Reduced normal transformation
(Z) was applied to standardize the data to eliminate the effect of different metric scales in calculating the principal components. Two methods were employed to choose descriptors, i.e., one based on direct selection proposed by Jolliffe (1973), and the other on selection with re-analysis proposed by Cury (1993). The first method eliminates the characteristics with the highest weighing coefficient in absolute value (eigenvector) in the principal component with the smallest eigenvalue until a threshold of 0.70 . The second method recommends carrying out a new analysis with the remaining characteristics whenever one is discarded, paying attention to the correlation between the redundant characteristic and the others. In addition, the process is stopped when a characteristic has a high correlation with at least one of the previously disposed characteristics.

The efficiency of the disposal process is attested by comparing the dissimilarity among groups of açai palms found at 11 different locations, based on characteristics originally proposed or selected after the disposal. The groups were formed using the average standardized Euclidean distance and Tocher's optimization method (CRUZ et al., 2011).

The estimates of the phenotypic differences obtained between different populations were calculated for 29 descriptors using the average value of each character. The average Euclidean distance was used to obtain these estimates along with standardized data $\left(\mathrm{d}_{\mathrm{ij}}\right)$ with the aim of eliminating the scaling between two different descriptors analyzed. The choice for this distance is justified by the origin of the data, i.e., not resulting from experimental designs (CRUZ et al., 2011) but obtained from açai palm mother plants randomly selected in the wild. The models used to standardize the data and obtain the Euclidean distance followed the recommendations of Cruz et al. (2011). All analyses were carried out with the GENES software (CRUZ, 2013). 
Table 1. Micro-region, municipality, place of selection, global position, and climate characterization of 148 açai palm mother plants selected in the archipelago of Marajó and lower Tocantins. Belém-PA, UFRA, 2015.

\begin{tabular}{|c|c|c|c|c|c|c|c|}
\hline Proc. & Mother plants $^{\mathrm{a}}$ & NM & $\mathbf{M R}^{\mathrm{b}}$ & Municipality & Place of selection & Time/Coordinate & Climate \\
\hline 1 & CM82 to CM92 & 8 & $\mathrm{AM}$ & Curralinho & $\begin{array}{l}\text { Upper Canaticu } \\
\text { River }\end{array}$ & $\begin{array}{c}\text { Time } 22 \mathrm{M} / \mathrm{E}=0639716 / \\
\mathrm{N}=9841611\end{array}$ & $\mathrm{Am}$ \\
\hline 2 & $\begin{array}{l}\text { CM55 to CM81; } \\
\text { CM85 to CM87 }\end{array}$ & 30 & $\mathrm{AM}$ & Curralinho & $\begin{array}{c}\text { Lower Canaticu } \\
\text { River }\end{array}$ & $\begin{array}{l}\text { Time } 22 \mathrm{M} / \mathrm{E}=0643307 / \\
\qquad \mathrm{N}=9810750\end{array}$ & $\mathrm{Am}$ \\
\hline 3 & CM01 to CM07 & 7 & $\mathrm{AM}$ & Curralinho & Piriá Mirim river & $\begin{array}{c}\text { Time } 22 \mathrm{M} / \mathrm{E}=0617714 / \\
\mathrm{N}=9828090\end{array}$ & $\mathrm{Am}$ \\
\hline 4 & $\begin{array}{l}\text { CM11 to CM23; } \\
\text { CM44 to CM47 }\end{array}$ & 17 & $\mathrm{AM}$ & Curralinho & $\begin{array}{l}\text { Confluence of } \\
\text { the Guajará and } \\
\text { Caruaca rivers }\end{array}$ & $\begin{array}{l}\text { Time } 22 \mathrm{M} / \mathrm{E}=0572370 / \\
\mathrm{N}=9828728\end{array}$ & $\mathrm{Am}$ \\
\hline 5 & CM48 to CM 54 & 7 & $\mathrm{AM}$ & Curralinho & $\begin{array}{c}\text { Confluence of the } \\
\text { Mutuacá and Três } \\
\text { Bocas rivers }\end{array}$ & $\begin{array}{c}\text { Time } 22 \mathrm{M} / \mathrm{E}=0588574 / \\
\mathrm{N}=9822104\end{array}$ & $\mathrm{Am}$ \\
\hline 6 & $\begin{array}{l}\text { CM08 to CM10; } \\
\text { CM25 to CM32 }\end{array}$ & 11 & $\mathrm{AM}$ & Curralinho & Lower Piriá river & $\begin{array}{c}\text { Time } 22 \mathrm{M} / \mathrm{E}=0604643 / \\
\mathrm{N}=9812365\end{array}$ & $\mathrm{Am}$ \\
\hline 7 & $\begin{array}{l}\text { CM24; CM33 to } \\
\text { CM43 }\end{array}$ & 12 & $\mathrm{AM}$ & Curralinho & Upper Piriá river & $\begin{array}{c}\text { Time } 22 \mathrm{M} / \mathrm{E}=615080 / \mathrm{N} \\
=9837501\end{array}$ & $\mathrm{Am}$ \\
\hline 8 & CA01 to CA10 & 10 & $\mathrm{AM}$ & $\begin{array}{l}\text { Cachoeira do } \\
\text { Arari }\end{array}$ & $\begin{array}{l}\text { Confluence of } \\
\text { the Gurupá and } \\
\text { Caracará rivers }\end{array}$ & $\begin{array}{c}\text { Time } 22 \mathrm{M} / \mathrm{E}=0746300 / \\
\mathrm{N}=9872388\end{array}$ & $\mathrm{Am}$ \\
\hline 9 & BV01 to BV13 & 13 & $\mathrm{AM}$ & Breves & Mapuá river & $\begin{array}{c}\text { Time } 22 \mathrm{M} / \mathrm{E}=0560363 \\
\mathrm{~N}=9884601\end{array}$ & $\mathrm{Am}$ \\
\hline 10 & ST01 to ST12 & 12 & $\mathrm{RG}$ & $\begin{array}{l}\text { Santa Isabel } \\
\text { do Pará }\end{array}$ & Guamá river & $\begin{array}{l}\text { Time } 22 \mathrm{M} / \mathrm{E}=0815283 / \\
\mathrm{N}=9831211\end{array}$ & Af \\
\hline 11 & IM01 to IM21 & 21 & BT & Igarapé Miri & Cají river & $\begin{array}{c}\text { Time } 22 \mathrm{M} / \mathrm{E}=0703091 / \\
\mathrm{N}=9768018\end{array}$ & $\mathrm{Am}$ \\
\hline
\end{tabular}

a. BV: Breves; CA: Cachoeira do Arari; CM: Curralinho; IM: Igarapé Miri; ST: Santa Isabel.

b. AM: Archipelago of Marajó; RG: Guamá river; BT: Lower Tocantins

Proc.: Sources; NM: number of mother plants per location; MR: micro-region of Pará.

Following the study of Oliveira et al. (2006), grouped in relation to plant, fruits, and agronomic 29 morphoagronomic descriptors were used and characters (Table 2). 
Table 2. Morphoagronomic descriptors used for the phenotypic characterization of 148 mother plants of açai palm. Belém-PA, UFRA, 2015.

\section{Descriptors}

\begin{tabular}{cc}
\hline Related to the Plant (n= 9) & Agronomic (n = 13) \\
\hline NEP: number of stems per plant (unit) & PC: weight of the bunch $(\mathrm{kg})$ \\
NEF: number of fruiting stems per plant (unit) & PFC: weight of the fruit per bunch (kg) \\
AE: stem height (m) & NCE: number of bunches per stem (unit) \\
CEN: internode length at breast height $(\mathrm{cm})$ & RFC: fruit yield per bunch (\%) \\
CAP: stem circumference at breast height $(\mathrm{cm})$ & CIC: bunch circumference (cm) \\
NMF: average number of leaves per stem (unit) & COC: bunch length (cm) \\
CFL: average length of the leaflet $(\mathrm{cm})$ & NRC: number of rachis per bunch (unit) \\
LFL: average width of the leaflet $(\mathrm{cm})$ & NFRb: average number of fruits per rachis at the \\
CF: length of the leaf $(\mathrm{m})$ & base of the bunch (unit) \\
Related to the Fruit (n $=7)$ & NFRm: average number of fruits per rachis in the \\
PCF: weight of hundred fruits $(\mathrm{g})$ & middle third of the bunch (unit) \\
DLF: longitudinal fruit diameter $(\mathrm{cm})$ & NFRa: average number of fruits per rachis at the \\
DTF: cross-sectional fruit diameter $(\mathrm{cm})$ & apex of the bunch (unit) \\
PMF: average fresh fruit weight $(\mathrm{g})$ & NMFR: average number of fruits per rachis (unit) \\
PFU: average wet fruit weight $(\mathrm{g})$ & NTF: total number of fruits (unit) \\
PMS: average wet seeds weight $(\mathrm{g})$ & TPC: total of pulp per bunch (kg) \\
RPF: pulp yield per fruit $(\%)$ &
\end{tabular}

\section{Results and Discussion}

The extraction of the principal components resulted in the collection of $48.23 \%$ of the total variance in the first two components, and comprised $96.74 \%$ of the variation in descending order until the seventeenth component (Table 3).

In a previous study on açai palm, Oliveira et al. (2006) obtained $35.8 \%$ of the total variation in the first two components and the variance was distributed until the sixth component. This accounted for $68.85 \%$ of the total variance when 87 accessions were analyzed using 28 morphoagronomic descriptors. In a similar study, Galate et al. (2012) obtained values lower than those presented in this study by comparing the variation of the first two components, which reached 42.09\%. Moreover, $68.65 \%$ of the total variance was accumulated within the first six components.

Using PCA, when the genotype groups are different, the majority of the total variation of the data is expected to be concentrated in the first two components (CRUZ; REGAZZI, 2008). However, this depends on the number and nature of the characters used in the analysis. Most of the variance is concentrated in the first components only if the number of agronomic descriptors is reduced or belongs to the same group. The analysis of the first components gives many details on the total variance of the data set if high correlations are observed between several characters (GALATE et al., 2012). 
Table 3. Estimate of eigenvalues associated with principal components and percentage and accumulated variance of 29 phenotypic characteristics among 148 mother plants of açai palm. Belém-PA, UFRA, 2015.

\begin{tabular}{|c|c|c|c|}
\hline Components & Eigenvalues & RV \% & AV \% \\
\hline 1 & 8.413 & 29.01 & 29.01 \\
\hline 2 & 5.573 & 19.22 & 48.23 \\
\hline 3 & 2.786 & 9.61 & 57.83 \\
\hline 4 & 1.803 & 6.22 & 64.05 \\
\hline 5 & 1.529 & 5.27 & 69.32 \\
\hline 6 & 1.272 & 4.39 & 73.71 \\
\hline 7 & 0.928 & 3.20 & 76.91 \\
\hline 8 & 0.873 & 3.01 & 79.92 \\
\hline 9 & 0.761 & 2.62 & 82.54 \\
\hline 10 & 0.698 & 2.41 & 84.95 \\
\hline 11 & 0.610 & 2.10 & 87.05 \\
\hline 12 & 0.595 & 2.05 & 89.10 \\
\hline 13 & 0.527 & 1.82 & 90.92 \\
\hline 14 & 0.488 & 1.68 & 92.60 \\
\hline 15 & 0.456 & 1.57 & 94.17 \\
\hline 16 & 0.381 & 1.31 & 95.49 \\
\hline 17 & 0.364 & 1.26 & 96.74 \\
\hline 18 & 0.279 & 0.96 & 97.70 \\
\hline 19 & 0.211 & 0.73 & 98.43 \\
\hline 20 & 0.173 & 0.60 & 99.03 \\
\hline 21 & 0.098 & 0.34 & 99.37 \\
\hline 22 & 0.074 & 0.26 & 99.62 \\
\hline 23 & 0.043 & 0.15 & 99.77 \\
\hline 24 & 0.037 & 0.13 & 99.90 \\
\hline 25 & 0.014 & 0.05 & 99.95 \\
\hline 26 & 0.008 & 0.03 & 99.97 \\
\hline 27 & 0.006 & 0.02 & 99.99 \\
\hline 28 & 0.002 & 0.01 & 100.00 \\
\hline 29 & 0.000 & 0.00 & 100.00 \\
\hline
\end{tabular}

$\mathrm{RV}$ : relative variance. $\mathrm{AV}$ : accumulated variance.

Our results show similarities in the distribution of the total variance when compared to the studies mentioned above, which also characterized the germplasm of açai palm. However, almost half of all variances were distributed in the first two components $(48.23 \%)$ and the proportion of the distribution until the sixth component was high (73.71\%). Galate et al. (2012) attributed such differences in the values of the variance distribution to the fact that there are differences in the origin of the accessions analyzed by Oliveira et al. (2006) and to the non-coincidence in the number of descriptors used in both studies.
Beside the 22 descriptors used to characterize the accessions of Northeastern Pará (GALATE et al., 2012), seven additional descriptors were used in this study. These descriptors are used to characterize açai palm germplasm for fruit production, and select plants according to the ideotype (OLIVEIRA et al., 2006). Therefore, the descriptors used in this study might explain possible similarities between the results presented here and those selected to characterize the accessions in Northeastern Pará.

In other studies involving palm trees, the variance values of the first two principal components were 
lower than those obtained in this study, e.g., $42.88 \%$ for the inajá palm, Maximiliana maripa (Aublet. Drude) (REDIG, 2013); 37.28\% for the date palm, Phoenix dactylifera L. (AHMED et al., 2011), and $33.86 \%$ for guarirobeira, Syagrus oleracea (Mart.) Becc.) (PINTO et al., 2010). On the other hand, in other studies, values higher than those obtained in this study were shown. For example, Santos (2010) obtained $55.35 \%$ variation concentrated in the first two principal components in the investigation of the genetic variation in natural populations of babassu (Orbignya phalerata Mart.); Martel et al. (2003) found that $59.2 \%$ of the total variation was concentrated in the first two components while characterizing the germplasm of the peach plant
(Bactris gasipaes Kunth.) using 40 morphological descriptors; and Santos (2010) obtained values of $58 \%, 65 \%$, and $61 \%$ of the total variance for oil palm (Elaeis guineensis Jacq.) from three different environments.

Descriptors selection was performed using two procedures: (i) direct selection and (ii) selection with reanalysis. Characters disposal using the direct selection method was performed on 20 characters (Table 4) that had the highest weighting coefficients in the principal components. Their eigenvalues were lower than 0.7 and the disposal process started from the last principal component.

Table 4. Identification of characters indicated to be disposed by direct selection according to eigenvectors associated with principal components. Data from 148 açai palm mother plants. Belém-PA, UFRA, 2015.

\begin{tabular}{ccc}
\hline Principal Components & Disposed descriptor & Associated eigenvectors \\
\hline CP29 & NMFR & 0.85 \\
CP28 & PFC & 0.81 \\
CP27 & PFU & 0.67 \\
CP26 & TPC & 0.68 \\
CP25 & NTF & 0.83 \\
CP24 & PSU & 0.75 \\
CP23 & PCF & 0.85 \\
CP22 & DTF & 0.87 \\
CP21 & NFRm & 0.72 \\
CP20 & PC & -0.41 \\
CP19 & NFRa & 0.7 \\
CP18 & CFL & 0.47 \\
CP17 & CIC & 0.45 \\
CP16 & CAP & -0.44 \\
CP15 & CF & -0.41 \\
CP14 & CEN & -0.41 \\
CP13 & NRC & 0.47 \\
CP12 & COC & 0.67 \\
CP11 & RFC & 0.41 \\
CP10 & DLF & 0.55 \\
\hline
\end{tabular}

By using direct selection, it was possible to dispose of the following 20 redundant descriptors: NMFR, PFC, PFU, TPC, NTF, PMS, PCF, DTF,
NFRm, PC, NFRa, CFL CIC, CAP, NEF, CEN, NRC, COC, NMF, and DLF (Table 5). 
Table 5. Pre-selected characters analyzed with the direct selection and selection wit re-analysis methods, and characters selected to describe açai palm. Belém-PA, UFRA, 2015.

\begin{tabular}{|c|c|c|c|}
\hline \multirow{2}{*}{ Characters } & \multicolumn{2}{|c|}{ Pre-selected } & \multirow{2}{*}{ Selected } \\
\hline & Direct Selection & Reanalyzed selection & \\
\hline NEP & PSEL & PSEL & SEL \\
\hline $\mathrm{NEF}$ & NPSEL $\left(15^{\circ}\right)$ & PSEL & SEL \\
\hline $\mathrm{AE}$ & PSEL & PSEL & SEL \\
\hline CEN & NPSEL $\left(16^{\circ}\right)$ & PSEL & SEL \\
\hline CAP & $\operatorname{NPSEL}\left(14^{\circ}\right)$ & PSEL & SEL \\
\hline NMF & NPSEL $\left(19^{\circ}\right)$ & PSEL & SEL \\
\hline $\mathrm{CFL}$ & $\operatorname{NPSEL}\left(12^{\circ}\right)$ & PSEL & SEL \\
\hline LFL & PSEL & PSEL & SEL \\
\hline $\mathrm{CF}$ & PSEL & PSEL & SEL \\
\hline $\mathrm{PC}$ & $\operatorname{NPSEL}\left(10^{\circ}\right)$ & PSEL & SEL \\
\hline $\mathrm{COC}$ & NPSEL $\left(18^{\circ}\right)$ & PSEL & SEL \\
\hline $\mathrm{CIC}$ & $\operatorname{NPSEL}\left(13^{\circ}\right)$ & PSEL & SEL \\
\hline NCE & PSEL & PSEL & SEL \\
\hline PFC & $\operatorname{NPSEL}\left(2^{\circ}\right)$ & $\operatorname{NPSEL}\left(2^{\circ}\right)$ & NSEL \\
\hline RFC & PSEL & PSEL & SEL \\
\hline PCF & $\operatorname{NPSEL}\left(7^{\circ}\right)$ & PSEL & SEL \\
\hline PMF & PSEL & $\operatorname{NPSEL}\left(6^{\circ}\right)$ & NSEL \\
\hline PFU & NPSEL $\left(3^{\circ}\right)$ & $\operatorname{NPSEL}\left(3^{\circ}\right)$ & NSEL \\
\hline PMS & $\operatorname{NPSEL}\left(6^{\circ}\right)$ & PSEL & SEL \\
\hline DLF & $\operatorname{NPSEL}\left(20^{\circ}\right)$ & PSEL & SEL \\
\hline DTF & NPSEL $\left(8^{\circ}\right)$ & PSEL & SEL \\
\hline RPF & PSEL & PSEL & SEL \\
\hline NRC & $\operatorname{NPSEL}\left(17^{\circ}\right)$ & PSEL & SEL \\
\hline $\mathrm{NFRb}$ & PSEL & PSEL & SEL \\
\hline NFRm & NPSEL $\left(9^{\circ}\right)$ & PSEL & SEL \\
\hline NFRa & $\operatorname{NPSEL}\left(11^{\circ}\right)$ & PSEL & SEL \\
\hline NMFR & $\operatorname{NPSEL}\left(1^{\circ}\right)$ & $\operatorname{NPSEL}\left(1^{\circ}\right)$ & NSEL \\
\hline NTF & $\operatorname{NPSEL}\left(5^{\circ}\right)$ & $\operatorname{NPSEL}\left(5^{\circ}\right)$ & NSEL \\
\hline TPC & NPSEL $\left(4^{\circ}\right)$ & NPSEL $\left(4^{\circ}\right)$ & NSEL \\
\hline
\end{tabular}

NPSEL: not pre-selected; PSEL: pre-selected; SEL: selected; NSEL: not selected.

The descriptors DTF, NMFR, PCF, NTF, and PFC presented the highest weight module associated with the principal components $22,29,23,25$, and 28, respectively. The first character to be disposed was NMFR, which presented a high weight coefficient module in the last principal component (0.848).

In the procedure involving reanalysis selection, only six descriptors were indicated to be disposed, and these followed a sequential order: NMFR, PFC, PFU, TPC, NTF, and PMF. From the last disposed descriptor (PMF), the seventh descriptor (PMS) violates the assumptions of the procedure. This presents a high PMF and PFU correlation (Table 6), both characters being disposed.
The selection with re-analysis method provided the lowest number of redundant descriptors, which were indicated as disposable. These descriptors were different from the 20 descriptors indicated by the direct selection, which, beside five that were common to the two methods (i.e., NMFR, PFC, PFU, TPC, and NTF), also included DTF, PSU, and NFRm. On the other hand, the selection with re-analysis method, except for the five common descriptors, only the PMF character was recommended to be disposed, thus reducing the reduction of the agronomic characters to four and that of fruits to two. 
Table 6. Pearson's correlation coefficients between selected and disposed phenotypic characters derived from 148 açai palm mother plants. Belém-PA, UFRA, 2015.

\begin{tabular}{|c|c|c|c|c|c|c|}
\hline \multirow{2}{*}{$\begin{array}{c}\text { Selected } \\
\text { Descriptors }\end{array}$} & \multicolumn{6}{|c|}{ Disposed Descriptors } \\
\hline & NMFR & PFC & PFU & TPC & NTF & PMF \\
\hline NEP & -0.04 & -0.07 & $0.17^{*}$ & -0.07 & -0.06 & $0.17^{*}$ \\
\hline NEF & 0.02 & 0.08 & $0.2^{*}$ & 0.07 & -0.01 & $0.21^{*}$ \\
\hline $\mathrm{AE}$ & 0.03 & 0.07 & -0.09 & 0.03 & $0.17^{*}$ & -0.1 \\
\hline CEN & -0.04 & 0.03 & 0.05 & 0.01 & 0.07 & 0.04 \\
\hline CAP & $0.17^{*}$ & $0.34^{* *}$ & 0.01 & $0.35^{* *}$ & $0.32^{* * *}$ & 0.01 \\
\hline NMF & $0.31^{* *}$ & $0.31^{* *}$ & -0.16 & $0.31^{* * *}$ & $0.35^{* *}$ & -0.16 \\
\hline CFL & $0.26^{* *}$ & $0.37^{* *}$ & -0.12 & $0.42^{* *}$ & $\mathbf{0 . 3 8}^{* * *}$ & -0.12 \\
\hline LFL & $0.16^{*}$ & $0.36^{* *}$ & $0.18^{*}$ & $0.36^{* *}$ & $0.25^{* *}$ & $0.19^{*}$ \\
\hline $\mathrm{CF}$ & $0.22^{* *}$ & $0.3^{* *}$ & 0.02 & $0.32^{* *}$ & $0.3^{* *}$ & 0.02 \\
\hline $\mathrm{PC}$ & $0.82^{* *}$ & $0.98^{* * *}$ & 0.07 & $0.94^{* *}$ & $0.86^{* *}$ & 0.07 \\
\hline $\mathrm{COC}$ & $0.19^{*}$ & $0.35^{\text {** }}$ & $0.26^{* *}$ & $0.3^{* *}$ & $0.25^{* *}$ & $0.26^{* * *}$ \\
\hline CIC & $0.21^{*}$ & $0.3^{* *}$ & -0.15 & $0.31^{* * *}$ & $0.34^{* *}$ & -0.15 \\
\hline NCE & $0.22^{* *}$ & $0.23^{\text {** }}$ & -0.14 & $0.25^{\text {** }}$ & $0.26^{* *}$ & -0.15 \\
\hline RFC & $0.44^{* *}$ & $0.49^{* *}$ & $0.23^{* *}$ & $0.46^{\text {** }}$ & $0.34^{* *}$ & $0.23^{* *}$ \\
\hline PCF & -0.14 & 0.14 & $0.96^{* *}$ & 0.1 & $-0.23^{* *}$ & $0.97^{* *}$ \\
\hline PMS & $-0.2^{*}$ & 0.07 & $0.98^{* *}$ & -0.03 & $-0.28^{* *}$ & $0.97^{* *}$ \\
\hline DLF & -0.04 & 0.15 & $0.51^{* *}$ & 0.15 & -0.09 & $0.5^{* *}$ \\
\hline DTF & -0.14 & 0.13 & $0.94^{* *}$ & 0.08 & $-0.23^{* *}$ & $0.94^{* * *}$ \\
\hline RPF & $0.19^{*}$ & 0.15 & -0.15 & $0.38^{* *}$ & $0.17^{*}$ & -0.15 \\
\hline NRC & $0.28^{* *}$ & $0.46^{* *}$ & $-0.25^{* *}$ & $0.43^{\text {** }}$ & $0.64^{* *}$ & $-0.25^{* *}$ \\
\hline $\mathrm{NFRb}$ & $0.95^{* *}$ & $0.85^{* *}$ & -0.16 & $0.84^{* *}$ & $0.89^{* *}$ & $-0.16^{*}$ \\
\hline NFRm & $0.95^{* *}$ & $0.78^{k * *}$ & $-0.19^{*}$ & $0.78^{* *}$ & $0.85^{\text {** }}$ & $-0.19^{*}$ \\
\hline NFRa & $0.89^{* *}$ & $0.71^{* *}$ & -0.12 & $0.7^{* *}$ & $0.76^{* *}$ & -0.12 \\
\hline
\end{tabular}

${ }^{*}$ and ${ }^{* *}$ : Significant at $5 \%$ and $1 \%$, respectively.

Thus, $20.69 \%$ of the characters originally proposed were disposed according to the direct selection method instead of $31.03 \%$. This resulted in 23 descriptors selected as sufficient to describe açai palm, which were used to characterize and evaluate its accessions.

These results, which were similar to those found by Oliveira et al. (2006) and Galate et al. (2012), according to which $21.43 \%$ and $36.36 \%$ of the characters were disposed, simplified the characterization and evaluation of the germplasm of açai palm by eliminating the redundancy of the originally proposed descriptors without losing information (CRUZ et al., 2004). Disposal of $11.74 \%$ of the characters evaluated for inajá palms allowed using 15 descriptors in the characterization and evaluation of the Active Banks of Germplasm of this palm tree (REDIG, 2013). In the study by Martel et al. (2003), disposal of $33.33 \%$ of the morphological descriptors allowed a successful characterization of the accessions of peach palms.

The Pearson's correlation coefficients between the six characters disposed and the 23 selected, demonstrated that the disposal process did not cause a significant loss of information because all redundant characteristics were associated with at least 11 of those that were selected (Table 6).

The PMF character, which is important in the evaluation of açai palm germplasm, was indicated to be disposed even though, it is highly associated $\left(r_{x y}>0.9\right)$ with three selected characteristics, i.e., PCF, PMS, and DTF, which were recommended to be disposed by Oliveira et al. (2006) and Galate et al. (2012), while other nine characteristics were 
considered of low magnitude. The weight of the fruit seems to be associated with the yield of the edible portion (RPF) and not with the dry matter content (ROGEZ, 2000).

Similar to other studies on descriptor selection for açai palm, the PFC character was disposed although it is a relevant indicator of fruit production (GALATE et al., 2012; OLIVEIRA et al., 2006). However, this descriptor is associated with other nine agronomic descriptors that were selected, such as PC, NFRb, NFRm, and NFRa $\left(r_{x y}>0.69\right)$, which allows its disposal without information loss.

No references were found in the literature on the other four disposable characters (i.e., NMFR, PFU, TPC, and NTF), which influence açai palm fruit production. However, since these characters have not been used previously and maintain highmagnitude associations $\left(\mathrm{r}_{\mathrm{xy}}>0.9\right)$ with three selected characters, the expectation is that their disposal does not damage the interpretation of phenotypic diversity and the identification of desirable individuals (OLIVEIRA, et al., 2006).
The 11 locations at which the açai palm mother plants were collected were divided into five groups when they were analyzed using the 29 proposed descriptors, and only into four groups when they were analyzed using the 23 selected descriptors (Table 7). Group 1 included the Lower Canaticu River (Baixo Rio Canaticu), the confluence of Mutuacá and Três Bocas rivers, the confluence of Guajará and Caruaca rivers, Lower Piriá river (Baixo Rio Piriá), Upper Piriá river (Alto Rio Pirá) and Piriá Mirim river, and all the municipality of Curralinho. Group 2 included the Lower Guamá river (Baixo Rio Guamá) in Santa Isabel do Pará and of Cají river in Igarapé Miri. Group 3, 4, and 5 included only one location each, i.e., the confluence of Gurupá and Caracará rivers in Cachoeira do Arari, the Lower Canaticu river (Alto Rio Canaticu) in Curralinho, and Mapuá river in Breves, respectively. On the other hand, the groups formed by the 23 selected descriptors were different in terms of number (i.e., four instead of 5) and origin clustering. In the second analysis, Mapuá river belongs to group 1 . These differences showed that the disposal process efficient.

Table 7. Dissimilarity groups obtained applying the Tocher's method to 148 mother plants collected form 11 origins, and based on 29 original and 23 selected characters. Belém-PA, UFRA, 2015.

\begin{tabular}{ccc}
\hline \multirow{2}{*}{ Group } & \multicolumn{2}{c}{ Origins } \\
\cline { 2 - 3 } 29 original characters & 23 selected characters \\
\hline 1 & $\begin{array}{c}\text { Lower Canaticu river, Confluences of Mutuacá } \\
\text { and Três Bocas rivers, Confluences of Guajará } \\
\text { and Caruaca rivers, Lower Piriá river, Upper Piriá } \\
\text { river, Piriá Mirim river }\end{array}$ & $\begin{array}{c}\text { Lower Canaticu river, Confluences of Mutuacá } \\
\text { and Três Bocas rivers, Confluences of Guajará } \\
\text { and Caruaca rivers, Lower Piriá river, Upper } \\
\text { Piriá river, Mapuá river, Piriá Mirim river }\end{array}$ \\
2 & Lower Guamá river, Cají river & Lower Guamá river, Cají river \\
3 & Confluence of Gurupá and Caracará rivers & Confluence of Gurupá and Caracará rivers \\
5 & Lower Canaticu river & Upper Canaticu river \\
\hline
\end{tabular}

When variables are disposed to reduce but minimal. Therefore, the selected characters redundancy, and thus to reduce the time cost of represent the phenotypic divergence of the evaluated the evaluation, information loss in inevitable set (CURY, 1993). 


\section{Conclusions}

The phenotypic variability was assessed for most of the morphoagronomic characters evaluated, which showed variance in the açai palm mother plants collected at different sites. Moreover, 79.31\% of the descriptors used was representative and was used to evaluate the germplasm of açai palm for fruit production. The Tocher's optimization method allowed the formation of different groups that can be used to establish a breeding program aimed to obtain better genotypes than those already existing.

\section{Acknowledgments}

The authors thank CAPES for granting the scholarship, to FINEP through the Project FRUTIPARÁ/SIPITSPARÁ for promoting the experimental activities, to the Incubadora Tecnológica de Empreendimentos Solidários of UFRA for supporting all the steps of the study, to the fellow investigators participating in the project and, in particular, to Milene Moara and Aline Pereira for conducting expeditions and sample collection and care; to the Graduate Program in Agricultural Sciences of UFRA for supporting expeditions aimed at selecting açai palm mother plants; and to all the communities visited for their crucial contribution to the implementation of the study.

\section{References}

AHMED, M. V. O. M.; BOUNA, Z. E. O.; LEMINE, F. M. M.; DJEH, T. K. O.; MOKHTAR, T.; SALEM, A. O. M. Use of multivariate analysis to assess phenotypic diversity of date palm (Phoenix dactylifera $\mathrm{L}$.) cultivars. Scientia Horticuturae, Amsterdam, v. 127, n. 1, p. 367371, 2011.

ARAujo, D. G. de; CARVAlHO, S. P.; ALVES, R. M. Divergência genética entre clones de cupuaçuzeiro (Theobroma grandiflorum Willd ex Spreng Schum). Ciência e Agrotecnologia, Lavras, v. 26, n. 1, p. 13-21, 2002.

CRUZ, C. D. GENES - a software package for analyses in experimental statistics and quantitative genetics. Acta Scientiarum, Maringá, v. 35, n. 3, p. 271-276, 2013.
CRUZ, C. D.; FERREIRA, F. M.; PESSONI, L. A. Biometria aplicada ao estudo da diversidade genética. Viçosa: UFV, 2011. 620 p.

CRUZ, C. D.; REGAZZI, A. J. Modelos biométricos aplicados ao melhoramento genético. 2. ed. Viçosa: UFV, 2008. $390 \mathrm{p}$.

CRUZ, C. D.; REGAZZI, J. A.; CARNEIRO, P. C. S. Divergência genética. In: CRUZ, C. D.; REGAZZI, J. A.; CARNEIRO, P. C. S. (Ed.). Modelos biométricos aplicados ao melhoramento genético. Viçosa: UFV, 2004. v. 1, p. 377-413.

CURY, R. Dinâmica evolutiva e caracterização de germoplasma de mandioca (Manihot esculenta, Crantz) na agricultura autóctone do sul do Estado de São Paulo. 1993. Dissertação (Mestrado) - Escola Superior de Agricultura Luiz de Queiroz, Universidade de São Paulo, Piracicaba.

FALCONER, D. S.; MACKAY, T. F. C. Introduction to quantitative genetics. 4. ed. England: Longman, 1996. $463 \mathrm{p}$.

FARIAS NETO, J. T. de; RESENDE, M. D. V. de; OLIVEIRA, M. S. P. de; SANTOS, N. S. A. dos; CANUTO, E. L.; NOGUEIRA, O. L.; MULLER, A. A. Avaliação genética de progênies de polinização aberta de açaí (Euterpe oleracea) e estimativas de parâmetros genéticos. Cerne, Lavras, v. 13, n. 4, p. 376-383, 2007.

FARIAS NETO, J. T. F.; RESENDE, M. D. V.; OLIVEIRA, M. S. P.; NOGUEIRA, O. L.; FALCÃO, P. N. B.; SANTOS, N. S. A. dos. Estimativas de parâmetros genéticos e ganhos de seleção em progênies de polinização aberta de açaizeiro. Revista Brasileira de Fruticultura, Jaboticabal, v. 30, n. 4, p. 1051-1056, 2008.

GALATE, R. S.; MOTA, M. G. C.; GAIA, J. M. D.; COSTA, M. S. S. Caracterização morfoagronômica de germoplasma de açaizeiro no nordeste paraense. Revista Brasileira de Fruticultura, Jaboticabal, v. 34, n. 2, p. 540-550, 2012.

GALATE, R. S.; MOTA, M. G. C.; GAIA, J. M. D.; COSTA, M. S. S. Distância fenotípica entre matrizes de açaizeiro (Euterpe oleracea Mart.) procedentes do nordeste do Pará. Semina: Ciências Agrárias, Londrina, v. 35, n. 4, p. 1667-1682, 2014.

HALLAUER, A. R.; MIRANDA FILHO, J. B. Quantitative genetics in maize breeding. Ames: Iowa State University Press, 468 p.

JOLLIFFE, I. T. Discarding variables in a principal component analysis. II: real data. Journal of the Royal Statistical Society Series C - Applied Statistics, London, v. 22, n. 1, p. 21-31, 1973. 
MARTEL, J. H. I.; FERRAUDO, A. S.; MÔRO, J. R.; PERECIN, D. Estatística multivariada na discriminação de raças amazônicas de pupunheiras (Bactris gasipaes Kunth.) em Manaus (Brasil). Revista Brasileira de Fruticultura, Jaboticabal, v. 25, n. 1, p. 115-118, 2003.

NASCIMENTO FILHO, F. J.; ATROCH, A. L.; SOUSA, N. R.; GARCIA, T. B.; CRAVO, M. S.; COUTINHO, E. F. Divergência genética entre clones de guaranazeiro. Pesquisa Agropecuária Brasileira, Brasília, v. 36, n. 3, p. 501-506, 2001.

NOGUEIRA, A. K. M.; SANTANA, A. C.; GARCIA, W. S. A. dinâmica do mercado de açaí fruto no Estado do Pará: de 1994 a 2009. Revista Ceres, Viçosa, v. 60, n. 3, p. 324-331, 2013.

OLIVEIRA, M. S. P.; SANTOS, J. B. dos; AMORIM, E. P.; FERREIRA, D. F. Variabilidade genética entre acessos de açaizeiro utilizando marcadores microssatélites. Ciência Agrotécnica, Lavras, v. 34, n. 5, p. 1253-1260, 2010.

OLIVEIRA, M. S. P.; FERREIRA, D. F.; SANTOS, J. B. Seleção de descritores para caracterização de germoplasma de açaizeiro para produção de frutos. Pesquisa Agropecuária Brasileira, Brasília, v. 41, n. 7, p. 1133-1140, 2006.

OLIVEIRA, M. S. P.; MOCHIUTTI, S.; FARIAS NETO, J. T. Domesticação e melhoramento de açaizeiro. In: BORÉM, A.; LOPES, M. T. G.; CLEMENT, C. R. Domesticação e melhoramento: espécies amazônicas. Viçosa, MG: UFV, 2009. p. 207-235.

OLIVEIRA. M. S. P.; FERREIRA, D. F.; SANTOS, J. B. Divergência genética entre acessos de açaizeiro fundamentada em descritores morfoagronômicos. Pesquisa Agropecuária Brasileira, Brasília, v. 42, n. 4, p. 501-506, 2007.
PINTO, J. F. N.; REIS, E. F. dos; FALEIRO, F. G.; BARBOSA, E. C. C.; NUNES, H. F.; PINTO, J. F. N. Seleção de descritores vegetativos para caracterização de acessos de guariroba (Syagrus oleracea (Mart.) Becc.). Revista Brasileira de Fruticultura, Jaboticabal, v. 32, n. 3, p. 01-08, 2010.

REDIG, M. S. F. Coleta, caracterização e avaliação de germoplasma de inajazeiro (Maximiana maripa (Aublet) Drude) do nordeste paraense. 2013. Tese (Doutorado em Ciências Agrárias) - Universidade Federal Rural da Amazônia, Belém.

ROGEZ, H. Açaí: preparo, composição e melhoramento da conservação. Belém: EDUFPA, 2000. 313 p.

SANTOS, E. A. Caracterização de dendezeiros (Elaeis guineensis Jacq.) subespontâneos com base na produção de frutos e cachos. 2010. Dissertação (Melhoramento em Plantas e Biotecnologia) - Curso de pós-graduação em Produção Vegetal. Universidade Estadual de Santa Cruz, Ilhéus.

SANTOS, M. F. Variação genética em populações naturais de babaçu (Orbignya phalerata Mart.) por marcadores morfoagronômicos e moleculares. 2011. Dissertação (Mestrado em Genética e Melhoramento) Universidade Federal do Piauí, Teresina.

YOKOMIZO, G. K.; QUEIROZ, J. A. L.; CAVALCANTE, E. S.; PINHEIRO, I. N.; SILVA, P. A. R. da; MOCHIUTTI, S. Caracterização fenotípica e genotípica de progênies de Euterpe oleracea coletados no Afuá-Pará nas condições do Amapá. Cerne, Lavras, v. 18 , n. 2, p. 205-213, 2012.

YOKOMIZO, G. K.; QUEIROZ, J. A. L.; MOCHIUTTI, S.; PINHEIRO, I. N.; SILVA, P. A. R. da. Desempenho de progênies de açaizeiros avaliadas para caracteres agronômicos no Estado do Amapá. Scientia Forestalis, Piracicaba, v. 38, n. 87, p. 367-376, 2010. 